Available online at GSC Online Press Directory

GSC Advanced Research and Reviews e-ISSN: 2582-4597, CODEN (USA): GARRC2

Journal homepage: https://www.gsconlinepress.com/journals/gscarr

(RESEARCH ARTICLE)

\title{
Assessing the effect of starch on density and caloric value in sawdust briquette for domestic energy utilization in North-Western Nigeria
}

\author{
Dantani Abdulmalik 1, ${ }^{*}$, Babangida Abubakar ${ }^{2}$, Mukhtar Ridwan Bunza ${ }^{1}$, Zagga Abubakar Idris ${ }^{1}$ \\ Abdulrashid Inuwa ${ }^{1}$ and Abanikanda Jubril Olatunde ${ }^{1}$ \\ 1 Department of Forestry and Wildlife Management, Bayero University Kano, P.M.B.3011. Kano State. \\ ${ }^{2}$ Department of Forestry and Environment, Usmanu Danfodiyo University Sokoto, P.M.B. 2346, Sokoto State.
}

Publication history: Received on 17 December 2020; revised on 25 December 2020; accepted on 28 December 2020

Article DOI: https://doi.org/10.30574/gscarr.2020.5.3.0129

\begin{abstract}
The effect of starch on density, caloric value and specific fuel consumption were assessed in this research. Composite sawdust briquettes were produced from the mixture of sawdust and starch within four treatments in a percentage ratio of 80:20 for treatment A, 70:30 for treatment B, 60:40 for treatment C and 50:50 for treatment D. Densification of the mixtures was achieved using a manually operating briquetting machine and starch gel was used as a binding agent. The performance of briquette produced was examined under controlled cooking test. Energy content was determined using oxygen bomb calorimeter. The results obtained from density according to treatments A, B, C and D respectively were $0.0002067 \mathrm{~kg} / \mathrm{cm}^{3}, 0.0002433 \mathrm{~kg} / \mathrm{cm}^{3}, 0.00025 \mathrm{~kg} / \mathrm{cm}^{3}$. Treatment D has the highest density of $0.00029 \mathrm{~kg} / \mathrm{cm}^{3} . \mathrm{The}$ caloric value was determined from the heat of combustion with treatment $\mathrm{B}$ having the highest energy content of $7.37 \mathrm{cal} / \mathrm{g}, \mathrm{C}=6.159 \mathrm{cal} / \mathrm{g}, \mathrm{A}=6.055 \mathrm{calg}$, and $\mathrm{D}=4.573 \mathrm{cal} / \mathrm{g}$. Specific fuel consumption was determined during controlled cooking test and the values for the respective treatments were $A=0.89 \mathrm{~g}, \mathrm{~B}=0.47 \mathrm{~g}, \mathrm{C}=0.64 \mathrm{~g}, \mathrm{D}=0.86 \mathrm{~g}$, and fire wood $=0.89 \mathrm{~g}$. Time taken to cook $200 \mathrm{~g}$ of rice was obtained using wrist watch and the values were: $\mathrm{A}=50 \mathrm{~min}, \mathrm{~B}=44 \mathrm{~min}$, $\mathrm{C}=48 \mathrm{~min}, \mathrm{D}=47 \mathrm{~min}$, and firewood had the highest value of $53 \mathrm{~min}$. Results showed that, increase in the quantity of starch led to increase in density of composites.
\end{abstract}

Keywords: Briquette; Biomass; Sawdust; Densification; Calorimeter; Caloric value.

\section{Introduction}

Wood is a predominant source of fuel in rural areas of the developing countries. About 200 million people in developing countries depend on the wood biomass for their daily domestic energy need [1]. The main problem with fuel wood utilization in Nigeria is inadequate supply in arid region of the country [2]. The production of Briquette from agricultural and wood residue would have an appreciable impact meeting domestic energy requirement in the country which has problems of fuel wood scarcity [3]. It was reported that the average world production of residue comprises 250 million tons of sawdust, 200 million tons of bark, and over 400 million tons of crooked log. It was estimated that $55 \%$ of wood biomass processed in the saw mills in Nigeria end up as a mill residue. The wood wastes generated in the country in 1998 were estimated to be 1.72 million $\mathrm{m}^{3}$ [4]. This composes of slabs, (63\%) bark (22\%) and sawdust (15\%). The slabs and barks are sometimes collected and used as firewood while sawdust can be converted to briquettes. It will be more useful as a source of fuel for domestic cooking. The problem of acute scarcity and deficit in supply of fuel wood has resulted in energy crisis in arid and semi-arid regions of the developing countries [5]. Fuel wood provides about 30\% of the total energy consumption in Africa, 17\% for the countries of Asia 16\% for the Latin American countries [1].

\footnotetext{
${ }^{*}$ Corresponding author: Dantani Abdulmalik

Department of Forestry and Wildlife Management, Bayero University Kano, P.M.B.3011. Kano State.

Copyright (C) 2020 Author(s) retain the copyright of this article. This article is published under the terms of the Creative Commons Attribution Liscense 4.0.
} 
Trees are being indiscriminately cut or felled to meet the fuel wood demand with no systematic replacement until recently when desertification and soil erosion were experienced in some parts of the country [6]. The implication of indiscriminate fuel wood cutting on tree diversity in the natural ecosystem per hectare in Nigeria has been established. The tree diversity index in the Savannah dropped from $14.9 \%$ to $11.8 \%$ before and after felling while in the rainforest, tree diversity before felling was put at $17.8 \%$, but dropped to $7.2 \%$ after logging [7]. There has been a considerable increase in the use of biomass energy worldwide in the recent years most especially in Sub-Saharan Africa. It is expected that global production of wood fuel will increase moderately from 1,885 million m3 in 2000 to 1,921 million m3 in 2010 and 1,954 million $\mathrm{m} 3$ in 2020 [8]. In 1997 alone, the proportion of total round wood production used for fuel wood in Africa was 89\% [9]. In the case of Nigeria, consumption of fuel wood rose from 60.3 million m3 in 1980 through 90.75 million m3 in 1994 to 97.6 million $\mathrm{m} 3$ in 2000 and has been predicted to rise to 110.619 million m3 by 2010.

Briquette simply refers to a block of compressed coal dust, charcoal or sawdust and wood chips used for fuel and kindling. Briquetting is the process of transforming the powdery or granular products into a more convenient solid size. This sometimes involves the use of binders (glue). These materials are compacted with the use of roller press. Production of briquette, using sawdust will provide an alternative source of fuel which will reduce the rate at which our forests and woodlands are exploited for fuel-wood, and also reduce the rate at which this sawdust pollutes our environment. During the last century, Africa's forest area has been reducing drastically. In a short period of ten years, between 1990 and 2000 alone, Africa lost about 17,000ha of forest annually (i.e. negative annual changes of $0.70 \%$ the highest of any continent in the world [11] perhaps partly because of sourcing wood for fuel. Wood constitutes about $80 \%$ of fuel supply in Africa as a result of increasing population; Briquette has come to stay in order to reduce the rate of the exploitation faced by our forest through conversion of these millions of cubic meters of sawdust as a source of fuel.

\section{Material and methods}

\subsection{Study Area}

The research was carried out in Sokoto Energy Research Centre (SERC) of Usmanu Danfodiyo University, Sokoto. Sokoto State has a landmass of $28,232.37 \mathrm{~km} 2$, the state is located between longitude $11^{0} 13^{\prime}$ to $13^{\circ} 50 \mathrm{E}$ and latitude $4^{0}$ to $6 \mathrm{~N}$. it is bordered in the North by Niger Republic Zamfara state to the East and Kebbi state to the South and West. [11]. It has population of about 4,244,399 [12]. Sokoto state fall within Sudan Savannah area of Nigeria which is characterized by few scattered trees, and grasses that cover about 30\% of the ground [13], these plant species include Adansonia digitata, Balanite aegyptica, Acacia nilotica, Cynodon dactylon, Andropogun gayanus [14]

The minimum and maximum temperatures are within the range of $190 \mathrm{C}$ and 380C respectively. The relative humidity ranges from 52 - 56\% [15]: Respectively. The warmest months are from February - April where the daytime temperature exceeds $45^{\circ} \mathrm{C}\left(1130^{\circ} \mathrm{f}\right)$ the highest temperature recorded was $47.2^{\circ} \mathrm{C}\left(117.0^{\circ} \mathrm{f}\right)$ which was the highest temperature recorded in Nigeria. The rainfall mostly starts in either early or late May and ends in September. The mean annual rainfall ranges from $500 \mathrm{~mm}$ to $1300 \mathrm{~mm}$ which is un-evenly distributed [16]. Dry season mostly comes around October and last up to September. Hammatan is windy and dusty, cold and dry seasons are both experience in the state. The soil in this area is mostly Sandy to loamy with low soil fertility particularly in primary nutrients e.g. Nitrogen, potassium, Phosphorus [17]

\subsection{Experimental Materials}

- Sawdust: This was collected from kara market in Sokoto metropolis. Quantities used for treatment are, $A=400 \mathrm{~g}$, $\mathrm{B}=350 \mathrm{~g}, \mathrm{C}=300 \mathrm{~g}, \mathrm{D}=250 \mathrm{~g}$.

- Starch: This was bought from Zuru Central Market. Previous studies by [18] have shown that cassava starch is an acceptable binder that closely the requirements of briquetting in terms of relatively high bonding strength, low cost, in offensive odour emission and minimal need for drying. The amount of starch used based on the treatment include, treatment $A=100 \mathrm{~g}, \mathrm{~B}=150 \mathrm{~g}, \mathrm{C}=200 \mathrm{~g}$ and treatment $\mathrm{D}=250 \mathrm{~g}$.

- Measuring Instrument: Weighting balance was used to measure the samples (Sawdust and starch) before compression and after production of the composite (before and after drying).

- Briquetting Machine: This is a machine locally made consisting of pipe, iron rod, metal sheath, piston etc. and was used to compress sawdust in to composite briquette. Grams of Food: $200 \mathrm{~g}$ of rice was used in controlled cooking test.

- Improved Wood Burning Stove: This was used in controlled cooking test.

- Timing Instrument: A clock was used to determine the time taken for every session during controlled cooking test. 
- Oxygen bomb calorimeter was used to determine the energy content of the composites

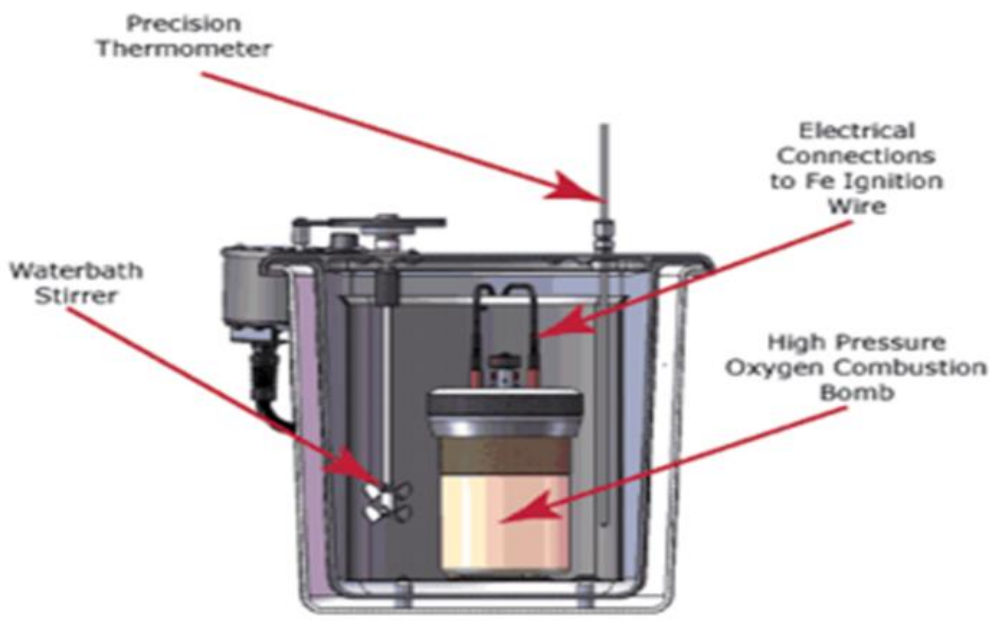

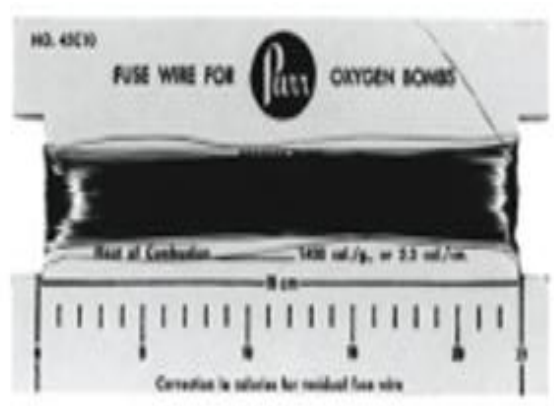

45C10 Fuse Wire

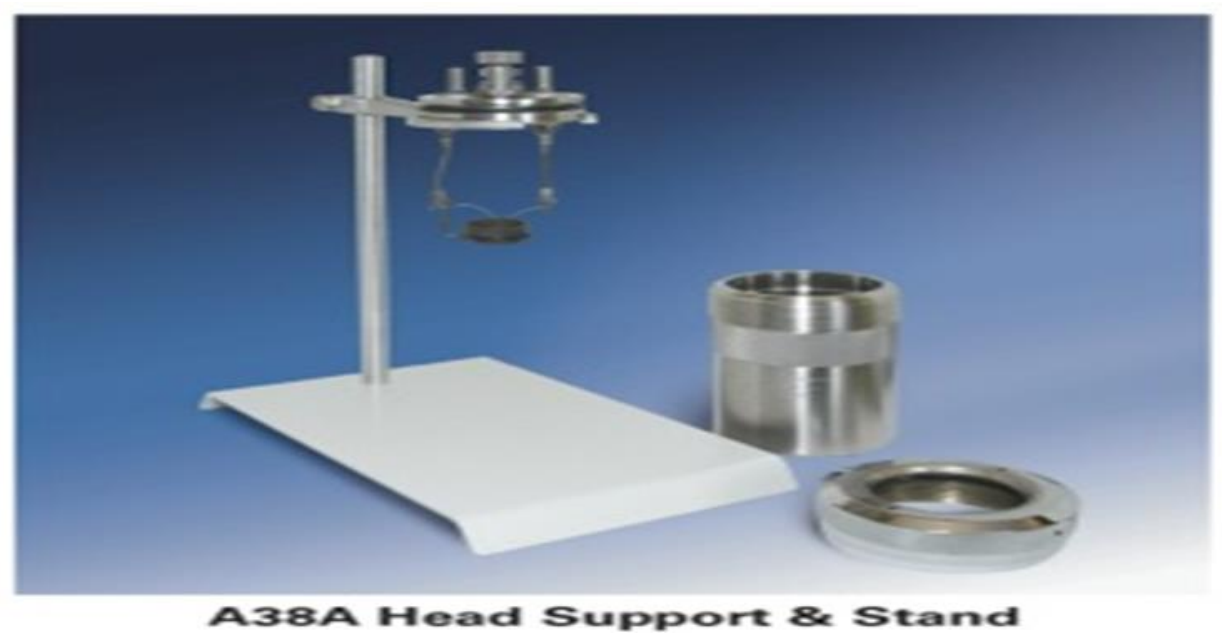

Figure 1 Oxygen Bomb Calorimeter

Density $=\frac{\text { Dry weight }}{\text { Wet weight }}$

Caloric value $=\frac{\mathrm{w}\left(\mathrm{cal} /{ }^{\circ} \mathrm{C}\right) \times \Delta \mathrm{T}\left({ }^{\circ} \mathrm{C}\right)-\text { wire correction }}{\operatorname{Arsh} \text { free dry weight }}$

$\mathrm{W}=$ the amount of energy in cal./ ${ }^{\circ} \mathrm{C}$, ? ? $=$ change in temperature

\subsection{Controlled Cooking Test (CCT)}

Controlled cooking test was carried out to cook $200 \mathrm{~g}$ of rice which was uniform for all the samples of briquette produced at different ratio of binder. Before the test, mass of the empty pot and initial mass of the briquette was measured.

\subsection{Specific Fuel Consumption (SFC)}

Specific fuel consumption and time taken to cook grams of food was computed from the equation below:

According to [19]. Specific Fuel Consumption (SFC) for a Controlled Cooking Test (CCT) is expressed as:

$$
S F C=\frac{(M f o-M f t)(1-X)}{M p c-M p} 1.5 M c
$$


where

$\mathrm{M}_{\mathrm{C}}=$ Mass of charcoal left (kg), $\mathrm{M}_{\mathrm{fo}}=$ Initial mass of fuel before burning (kg), $\mathrm{M}_{\mathrm{ft}}=$ Final mass of fuel burnt (kg), The mass of charcoal $\mathrm{M}_{\mathrm{c}}$ left after the briquette were combusted will be negligible hence $\mathrm{M}_{\mathrm{c}}$ is assumed to be zero.

According to [19]. The time spent in controlled cooking test is given as:

$t=\frac{\text { total time spent in cooking }}{\text { total mass of cooked food }} \quad$ i.e $\quad t=\frac{t_{0}-t_{1}}{M_{p c}-M_{p}}$

Where: $\mathrm{t}=$ Cooking time for $1 \mathrm{~kg}$ of food stuff $(\mathrm{min} / \mathrm{kg}), \mathrm{t}_{0}=$ Initial time before cooking $(\mathrm{min}), \mathrm{t}_{1}=$ Final time after cooking ( $\mathrm{min}$ ), $\mathrm{M}_{\mathrm{pc}}=$ Mass of pot with cooked food (kg), $\mathrm{M}_{\mathrm{p}}=$ Mass of empty pot, $\mathrm{X}=$ The moisture content value of fuel assumed to be zero i.e. $100 \%$ dryness.

\subsection{Experimental Design}

Complete randomized design was used to test the effect of additive (binder) in sawdust briquette at each level of composition or ratio of sawdust to additive which are in four treatments, replicated three times. The briquettes produced from the above combination were subjected to ANOVA to test for significant difference between the treatments.

\subsection{Data Collections}

Sampled sawdust and binder were simultaneously measured using electronic weighting balance before the mixture. Data were collected from compressed briquette produced before and after8- drying. Four Treatments replicated three times

$\begin{array}{llc}\text { Treatments/Mixtures } & \text { Percentage } & \text { Ratio } \\ \text { A: SD 400g } \rightarrow \text { ST 100g } & 80 \%-20 \% & 4: 1 \\ \text { B: SD 350g } \rightarrow \text { ST 150g } & 70 \%-30 \% & 7: 1 \\ \text { C: SD 300g } \rightarrow \text { ST 200g } & 60 \%-40 \% & 3: 2 \\ \text { D: SD 250g } \rightarrow \text { ST 250g } & 50 \% 50 & 1: 1\end{array}$

Before controlled cooking test, the weight of the composite briquette and weight of the firewood were measured. Density of the composite was also determined the test was also carried out between the best treatment and the firewood to see the possibility of replacing firewood with briquette to reduce the rate of exploitation of our natural forests.

\subsection{Data Analysis}

The data obtained from the experiment were subjected to (ANOVA) analysis of variance to test the performance of composite briquette to see whether there is significant difference in the composites produced at $5 \%$ level of significance and the best treatment was tested against firewood. SPSS Statistical Package version 20 was used.

\section{Results}

\subsection{Density}

The results in table 1 shows the mean density of the briquettes produced from four different treatments made of the following combinations of sawdust and starch. Treatment $A=80: 20$ of sawdust and starch, Treatment $B=70: 30$, Treatment $C=60: 40$, Treatment $D=50: 50$ respectively. It was observed that there was significant difference between the treatments $(\mathrm{p}<0.05)$. The highest density was recorded in treatment $\quad \mathrm{D}=0.2900 \mathrm{~g} / \mathrm{cm}^{3}$, followed by treatment $\mathrm{C}=0.2433 \mathrm{~g} / \mathrm{cm}^{3}$, treatment $\mathrm{B}=0.2500 \mathrm{~g} / \mathrm{cm}^{3}$, and the least was found to be treatment A with $0.2067 \mathrm{~g} / \mathrm{cm}^{3}$, this indicate that increase in the quantity of starch leads to the increase in density of the composites produced. 
Table 1 Mean density $\left(\mathrm{g} / \mathrm{cm}^{3}\right)$ of the composite briquettes in treatments (A, B, C, D)

\begin{tabular}{|l|l|l|}
\hline S/no & Treatments & Mean and SD \\
\hline 1 & A & $0.2067 \pm 0.04^{\mathrm{b}}$ \\
\hline 2 & B & $0.2433 \pm 0.05^{\mathrm{ab}}$ \\
\hline 3 & C & $0.2500 \pm 0.02^{\mathrm{ab}}$ \\
\hline 4 & D & $0.2900 \pm 0.04^{\mathrm{a}}$ \\
\hline
\end{tabular}

Means followed by the same letter are not statistically different according to Duncan Multiple Range Test (DMRT) at 5\% level of significance.

\subsection{Energy (Caloric Value)}

Table 2 shows the mean energy of the briquettes produced, with treatment B having the highest mean $(7.347 \mathrm{cal})$ and the lowest mean was recorded in treatment $\mathrm{D}$ with value of $4.572 \mathrm{cal}$. Statistically there is no significant difference between the energy content of the briquettes produced.

Table 2 Mean energy (Cal/g) obtained from sampled briquettes based on treatments (A, B, C, D)

\begin{tabular}{|l|l|l|}
\hline S/no & Treatment & Mean and SE \\
\hline 1 & A & $6.015 \pm 6.94^{\mathrm{ns}}$ \\
\hline 2 & B & $7.347 \pm 3.46^{\mathrm{ns}}$ \\
\hline 3 & C & $6.159 \pm 6.72^{\mathrm{ns}}$ \\
\hline 4 & D & $4.572 \pm 3.34^{\mathrm{ns}}$ \\
\hline
\end{tabular}

\subsection{Specific Fuel Consumption (SFC) and Time Spent in Cooking}

According to the research carried out it was observed that the lowest value of fuel consumed by $200 \mathrm{~g}$ of rice was recorded in treatment $B$ with about $0.47 \mathrm{~g}$, followed by $\mathrm{C}$ with $0.64 \mathrm{~g}$, D with value of 0.86 and $\mathrm{A}$ with value of $0.89 \mathrm{~g}$. Time spent in cooking $200 \mathrm{~g}$ of rice, the least was recorded in treatment $B$ with about $44 \mathrm{~min} / \mathrm{kg}, \mathrm{D}=47 \mathrm{~min} / \mathrm{kg}, \mathrm{C}=48 \mathrm{~min} / \mathrm{kg}$ and $\mathrm{A}=50 \mathrm{~min} / \mathrm{kg}$ and firewood $53 \mathrm{~min} / \mathrm{kg}$.

Table 3 Values obtained in specific fuel consumption (SFC) and time spent in cooking (TSC) 200g of rice. Treatment A, $\mathrm{B}, \mathrm{C}, \mathrm{D}$ and firewood.

\begin{tabular}{|l|l|l|l|}
\hline S/no & Treatments & S.F.C (g) & Time (min/kg) \\
\hline 1 & A & 0.89 & 50 \\
\hline 2 & B & 0.47 & 44 \\
\hline 3 & C & 0.64 & 48 \\
\hline 4 & D & 0.86 & 47 \\
\hline 5 & Firewood & 0.89 & 53 \\
\hline
\end{tabular}

\section{Discussion}

\subsection{Density}

The density of the composites produced was found to increase down the treatment with A having average density of about $0.00020 \mathrm{~kg} / \mathrm{cm}^{3}, \mathrm{~B}=0.00024 \mathrm{~kg} / \mathrm{cm}^{3}, \mathrm{C}=0.00025 \mathrm{~g} / \mathrm{cm}^{3}, \mathrm{D}=0.00029 \mathrm{~kg} / \mathrm{cm}^{3}$ which was the highest density recorded. 
From the research, it was deduced that increase in the amount of starch in a treatment leads to increase in the density of the briquette that will be produced and also influence compaction of the composites.

\subsection{Energy content (caloric value)}

The energy content of the composites produced was determined using oxygen bomb calorimeter and the following values were obtained $A=6015.36$ calories/ gram for $80 \%$ sawdust and $20 \%$ starch, $\mathrm{B}$ which has the highest energy content was found to be 7347.6 calories per gram, $C=6159.55$ calories per gram, $D=4572.26$ calories $/$ gram which was the lowest Caloric value recorded and these varied with the findings of [20] who said that energy content of the composite briquette was found to be $22.41 \mathrm{mj} / \mathrm{kg}$. These indicate that the energy content found in this experiment is higher than that of the above authors.

\subsection{Specific fuel consumption (S.F.C)}

This was found to be lowest in treatment B with about $0.47 \mathrm{~g}$ produced from the mixture of sawdust and starch at 70 and 30 percent, firewood was found to be $89 \mathrm{~g}$ and this correspond with the value obtained in treatment $\mathrm{A}$, but all the rest of the treatment have better S.F.C than the firewood and this contradict with the finding of [20] who reported that rice has a S.F.C of $0.185 \mathrm{~g}$, though the quality of rice was not stated. It can still be conducted that this experiment has the higher value of S.F.C in cooking than what was discovered by [20]

The minimum quality of cassava starch required for briquette production, As reported by [21] that it was impossible to produce any cohesive and stable briquette at a cassava content of 50\%, 100\% and 150\% as they all simply fell apart after production and this is not in conformity with my finding. It was only treatment $A$ that had such problem where the sawdust and the starch are in mixture of $80 \%$ and $20 \%$ respectively all the rest remain solid and this indicate that this level of binders are efficient. Mc=mass of charcoal left is 1.5g as constant, but it was reported by [20] that the mass of charcoal (mc) after combustion of the composites was found to be negligible hence mc is assumed to be zero. This is in total disagreement with my findings because at any stage of the test some quantities of charcoal were left behind.

\subsection{Time spent in cooking}

Time spent in cooking $200 \mathrm{~g}$ of rice are as follows for treatment $\mathrm{A}=50 \mathrm{~min} / \mathrm{kg}, \mathrm{B}=44 \mathrm{~min} / \mathrm{kg}, \mathrm{C}=48 \mathrm{~min} / \mathrm{kg}$, and $\mathrm{D}=47 \mathrm{~min} / \mathrm{kg}$ where by the firewood was recorded with highest time spend in cooking with about 53min/kg. [20] reported that briquette produced using starch only, rice about $40.38 \mathrm{~min} / \mathrm{kg}$, while in my research the lowest time was $44 \mathrm{~min} / \mathrm{kg}$, though foreign rice was used in the test.

\section{Conclusion}

Investigation of composite sawdust briquette as a source of fuel for domestic utilization was carried out in this research. It was observed that, composite briquette when used for cooking $200 \mathrm{~g}$ of rice have lower specific fuel consumption than the firewood. Also, the specific fuel consumption and time taken to cook certain amount of food depend on the type of food irrespective of the type of fuel used. In terms of the performance, it can be concluded that treatment B, C and D are better than fuel-wood. Similarly, consideration factor such as desertification, soil erosion, flood, occur mostly as a result of exploitation of timber (forests), briquette provide a cleaner environment because it releases very low amount of CO2 compare to fuel wood, it is also economical to produce, store and handle than the firewood.

The researchers strongly recommend that

- There is a strong need for public enlightenment about briquette production which will serve as a salient factor for forest conservation and environmental sanitation.

- Research should be geared in this area to explore different binders and material that can be converted into composites for energy application in our homes to reduce or solve the issue of energy crisis.

- Machines and equipment necessary for production of briquette should be provided at subsidized rate to make production of briquette in mass so that it can be available and affordable for the masses.

\section{Compliance with ethical standards}

\section{Acknowledgments}

We appreciate the contribution of Late Dr. AA Malami for his guidance and supervision of this research as well as the staff of Sokoto Energy Research Center Biomass Unit for their contributions throughout the laboratory work. 


\section{Disclosure of conflict of interest}

No any conflict of interest among authors

\section{References}

[1] Food and Agricultural Organisation. Tropical Forestry Action Plan Fuel-wood Energy. Unasylva. 38: 37-63.

[2] Fuwape JA, Sobanke AO. Combustion Characteristics of Wood Briquette Produced from Sawdust. National Conference of Nigeria Society of Agricultural Engineering.1998; 1-11 8 - 11th September.

[3] Food and Agricultural Organisation. The Briquetting of Agricultural wastes for Fuel Environment and Forestry. 1990; 11: 2-18.

[4] Badejo SO. Sawdust Utilization for Building materials manufacturing in Nigeria. Technical report Forestry Research Institute of Nigeria, Ibadan. January 2001.

[5] Fuwape JA. Combating Fuel-wood Crisis in Africa and Latin America. Scottish forestry. 1992; 26: 36-144.

[6] Garba B, Sambo AS. Comparative Performance Studies of two Metallic Fuel wood Store, Published by Nigerian Journal of Stores Energy. 1993; (12): 18 - 27.

[7] Osemeobo GJ. Fuel wood exploitation from Natural Ecosystem in Nigeria. Socioeconomic and ecological implication. Journal of Rural Development. 1992; 11(2): 141-155.

[8] Broadhead J, Bahdon J, Whiteman A. Past trend and Future Prospects for the Utilization of Wood Energy. Annexes 1 and 2. Global Forest Products outlook study working paper No. GFPOS/WP/O5 Food and Agriculture of the United Nations, Rome, Italy. 2001.

[9] Food and Agricultural Organisation. An international journal of forestry and forest industry. 2004; 55(4): 67-89.

[10] Food and Agricultural Organisation. An international journal of forestry and forest industries. 2002; 53-61.

[11] Sokoto State Tourist guide. Paper presented in Trade-fare Old Airport. Sokoto state under Ministry of Commerce Sokoto. 2010; 4.

[12] National Population Commission. Provisional Census Figure. Abuja Nigeria. 2006; 1-3.

[13] Baba KM, Alhassan AH. Impact of Animal Traction on Agricultural Production and Farm Income in Sokoto State. Nigeria Journal of Agriculture and Environment. 2000; 1(1): 15-22.

[14] Aliyu OM. Phenotypic correlation and path coefficient analysis if nut yield and yield components in cashew (Anarcardium occidentale L.) Silvae Genetica. 2006; 55(1): 19-25.

[15] Senchi AA. Preliminary studies of Germination Techniques for the seed of Gum Arabic (Acacia Senegal L. wild) (unpublished material). 2005.

[16] Ojanuga AG. Agro ecological zones map of Nigeria. Nutritional special programme for Food Security. FAOUNESCO. 2004; 124.

[17] Fatubarin A. Tropical Ecology, Higher education handbook series No.1decency printers and stationaries, Ilorin. 2004; 68-71.

[18] Olorunnisola OA. The performance of sawdust briquettes combusted in a conventional coal store. The Nigerian Journal of Forestry.1998; 28(1): 15 - 18.

[19] Danshehu BG, Sambo AS. Musa M. Comparative Performance of Sawdust and Wood Burning stove, Nigerian Journal of Renewable Energy. 1992; 3(1\&2): 50.

[20] Adegoke CO, Kuti OA. Investigation of Composite Sawdust Briquette as A Source of Fuel for Domestic Cooking. FUTAJEET, 2004; 14: 2144-150.

[21] Olorunnisola AO. Briquetting Rattan Furniture Waste for Domestic and Agro-Industrial Application. Nigerian journal of Renewable Energy. 2003; 11(1\&2): 130-135. 